\begin{tabular}{|c|c|}
\hline \multicolumn{2}{|c|}{ Advertisers in This Issue } \\
\hline & Page No. \\
\hline BOMEM & 18 \\
\hline Burleigh Instruments & 24 \\
\hline Cookson Plasmaterials & 45 \\
\hline Digital Instruments & 15 \\
\hline Elsevier & 81,86 \\
\hline FEI Company & 5 \\
\hline $\begin{array}{l}\text { High Voltage Engineering } \\
\text { Europa B.V. }\end{array}$ & inside front cover \\
\hline Lake Shore Cryotronics & back cover \\
\hline MDC Vacuum Products & 6 \\
\hline Micro Optics & 20 \\
\hline MKS Instruments & 19 \\
\hline Nano Instruments & 16 \\
\hline Park Scientific & 8 \\
\hline Philips Electronics & 1 \\
\hline Pure Tech & 17 \\
\hline Quantum Design & inside back cover \\
\hline Tencor Instruments & 2 \\
\hline VCH Publishers & 68 \\
\hline Virginia Semiconductor & 20 \\
\hline Voltaix & 69 \\
\hline $\begin{array}{l}\text { For free information about } \\
\text { services offered in this iss } \\
\text { the Reader Service Card, } \\
922-3165 \text {. }\end{array}$ & $\begin{array}{l}\text { the products and } \\
\text { le, fill out and mail } \\
\text { r FAX it to (312) }\end{array}$ \\
\hline
\end{tabular}

\begin{tabular}{|c|}
\hline \\
\hline 1992 \\
MRS Fall Meeting \\
November 30 - \\
December 4, 1992 \\
Boston, Massachusetts \\
For information, contact: \\
Materials Research Society \\
9800 McKnight Road \\
Pittsburgh, PA 15237 \\
Phone (412) 367-3003 \\
Fax (412) 367-4373 \\
\hline
\end{tabular}

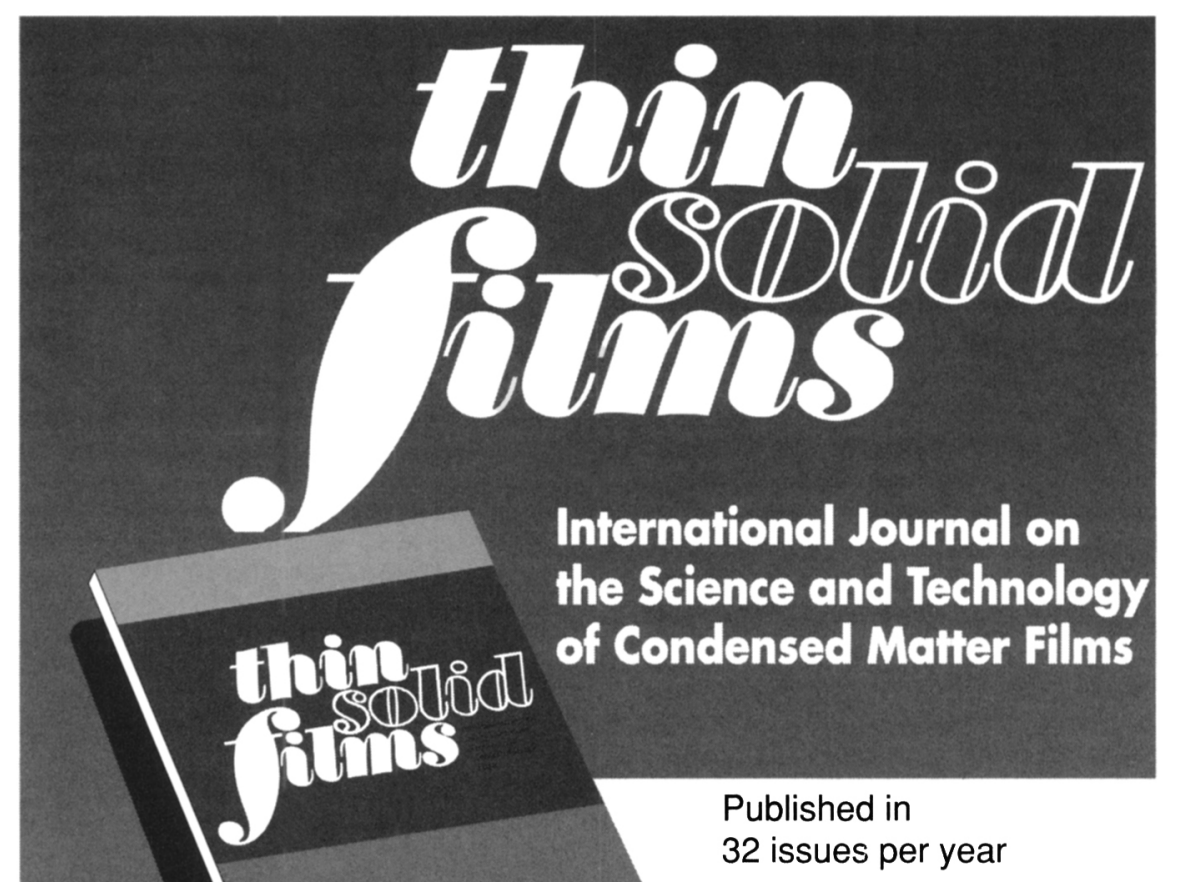

Editor-in-Chief:

\section{J.E. Greene}

University of Illinois at Urbana Coordinated Science Laboratory Urbana, IL, U.S.A.
Scientists

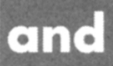

Engineers
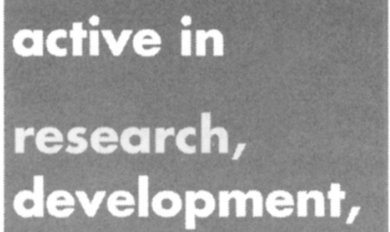

and

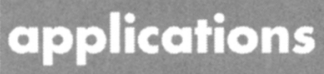

8

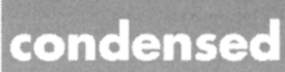
melier films
The journal Thin Solid Films is in a unique position to both reflect developments in the evolving field of thin films and to provide guidance and coherence. The field of thin films, which can be defined as the confluence of materials science, surface science, and applied physics, has become an identifiable unified discipline of scientific endeavor. The scope of Thin Solid Films is indicated by, but not limited to, the following topical subheadings:

A. Synthesis and Characterization

B. Surfaces, Interfaces, and Colloidal Behavior

C. Metallurgical, Protective, and Hard Layers

D. Mechanics and Nanomechanics of Thin Layers

E. Electronics, Optics, and Opto-electronics

F. Magnetics and Magneto-optics

G. Superconductivity

H. Langmuir-Blodgett, Biological, and Related Films

I. Thin Film Devices, Sensors, and Actuators

J. Condensed Matter Film Behavior

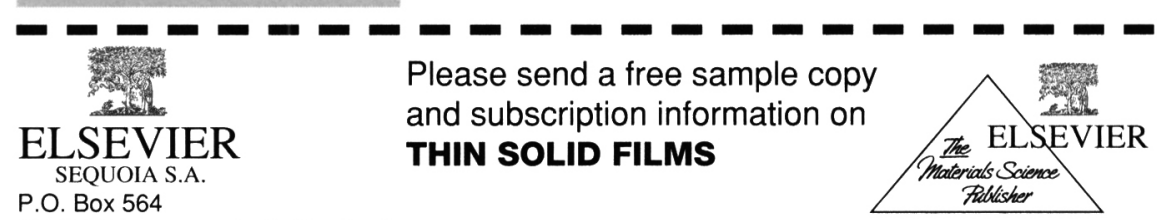

$\mathrm{CH}-1001$ Lausanne 1, Switzerland

Tel.: +41 (21) 207381

Fax: +41(21) 235444

For customers in the U.S.A. and Canada:

Elsevier Science

Publishing Co., Inc.

Attn.: Journal Information Center

655 Avenue of the Americas

New York, NY 10010, U.S.A.

Tel.: +1 (212) 633-3750

Fax: +1 (212) 633-3764
Please send a free sample copy and subscription information on

THIN SOLID FILIMS

Name:

Company/Institute:

Street:

City:

Country:

Postal Code:

Date: Signature: 